九州大学学術情報リポジトリ

Kyushu University Institutional Repository

\title{
Water-Soluble and Exchangeable Components of Vietnam Acid Sulfate Soils
}

Tho, Huynh-tong

Laboratory of Soils, Faculty of Agriculture, Kyushu University

Egashira, Kazuhiko

Laboratory of Soils, Faculty of Agriculture, Kyushu University

https://doi.org/10.5109/23652

出版情報 : 九州大学大学院農学研究院紀要. 22 (1/2)，pp.75-82，1977-10. Kyushu University バージョン：

権利関係 : 


\title{
Water-Soluble and Exchangeable Components of Vietnam Acid Sulfate Soils
}

\author{
Huynh-tong-Tho and Kazuhiko Egashira \\ Laboratory of Soils, Faculty of Agriculture. \\ Kyushu University 46-02, Fukuoka 812 \\ (Received August 8, 1977)
}

\begin{abstract}
Water-soluble and exchangeable components of Vietnam acid sulfate soils were analyzed. Large amounts of water-soluble $\mathrm{Fe}, \mathrm{Al}, \mathrm{Ca}$ and $\mathrm{Mg}$ sulfates and sulfuric acid were found. Their amount and the ratio of the amounts of water-soluble ions to those of the exchangeable ions increased with the decreasing pH. The strong acidity at low $\mathrm{pH}(<2.7)$ was due to water-soluble $\mathrm{Fe}$ and $\mathrm{Al}$ sulfates. At $\mathrm{pH} 12.8$. water-soluble $\mathrm{Fe}^{3+}$ disappeared and the contribution to the acidity of exchangeable $\mathrm{Al}^{3+}$ and Al sulfate increased. The amount of water-soluble $\mathrm{Ca}^{2+}+\mathrm{Mg}^{2+}$ (17-44 me/ $100 \mathrm{~g}$ ) was higher than that of acid sulfate soils from other countries.

The treatment with $\mathrm{H}_{2} \mathrm{O}_{2}$ caused the remarkable increase of water-soluble $\mathrm{Fe}^{3^{+}}, \mathrm{Al}^{3^{+}}$, $\mathrm{H}^{+}$and $\mathrm{SO}_{4}{ }^{2-}$ especially in subsoil layers. This indicates the high potential acidity derived from sulfides and the liberation of Al from organic matter.
\end{abstract}

\section{INTRODUCTION}

Acid sulfate soils are derived usually from marine and estuarine sediments high in sulfides (mainly pyrite, $\mathrm{FeS}_{2}$ ). The marine sediments are usually neutral to slightly alkaline when submerged. Upon drainage and aeration, large amounts of sulfides are oxidized to sulfuric acid, resulting in extremely strong acidity. Acid sulfate soils cover large areas in tropical and subtropical regions (Moormann, 1963). They occupy about 2 million hectares in the southern part of the Mekong delta in Vietnam (Pham-huu-Anh et al., 1961).

Acid sulfate soils have drawn considerable attention recently. Bloomfield (1972) studied the oxidation of iron sulfides in soils and stated that aerating pyritic soils causes acidification and the formation of acid sulfate soils, or cat-clay. Calvert and Ford (1973) investigated acid sulfate soils from Florida marshland and recognized that the high potential for developing acid sulfates is due to the unoxidized S. A high $\mathrm{S}$ level is confirmation that low $\mathrm{pH}$ values of 3.0 or below after oxidation with $\mathrm{H}_{2} \mathrm{O}_{2}$ are caused by pyrite. Horn et al. (1967) investigated coastal alluvial soils of the Republic of Guinea and stated that drainage of acid sulfate soils permits oxidation and the formation of $\mathrm{H}_{2} \mathrm{SO}_{4}$, resulting low $\mathrm{pH}$ values in the range of 2.5 to 4.0. The data on their chemical properties showed considerable amounts of water-soluble components, especially $\mathrm{Na}, \mathrm{Mg}, \mathrm{Cl}$ and $\mathrm{SO}$, (Horn and Chapman, 1968). Murakami (1968a) investigated the characteristics and improvement of acid sulfate soils from Naka-umi, Japan and reported that $\mathrm{S}$ is oxidized and produces high acidity, 
and that consequently a large amount of water-soluble $\mathrm{Al}, \mathrm{Fe}, \mathrm{Mn}$ and free acid are formed. Allbrook (quoted from Bloomfield and Coulter (1973)) extracted Al from acid sulfate soils in Malaysia using a $1: 1$ soil water ratio and reported $8.5 \mathrm{me} / 100 \mathrm{~g}$ of soluble $\mathrm{Al}$ from a soil which had $3 \% \mathrm{~S}$. Lefebre-Drouet (quoted from Bloomfield and Coulter, 1973) found that the destruction of organic matter in acid soils with $\mathrm{H}_{2} \mathrm{O}_{2}$ liberates large quantities of Al. Sompatpanit (quoted from Bloomfield and Coulter, 1973) quoted 3.5-5.0 me/100 g exchangeable $\mathrm{Ca}$ and $3.0-3.2 \mathrm{me} / 100 \mathrm{~g}$ exchangeable $\mathrm{Mg}$ in the top $35 \mathrm{~cm}$ of an acid sulfate soil in Thailand. Amounts of this order were also given by Mai-thi-my-Nhung and Ponnamperuma (1966) for a soil from Vietnam. Pham-huu-Anh et al. (1961) gave $3.0 \mathrm{me} / 100 \mathrm{~g}$ exchangeable $\mathrm{Ca}$ in the $\mathrm{O}-35 \mathrm{~cm}$ horizon, 2.9 in the "cat" clay horizon, and 3.6 in the reduced horizon; corresponding figures for $\mathrm{Mg}$ were $4.1,5.7$ and 9.0 .

In the previous paper (Huynh-tong-Tho and Egashira, 1976), some chemical, physical and mineralogical properties of Vietnam acid sulfate soils were investigated. They contained large amounts of extractable $\mathrm{Fe}^{3+}, \mathrm{Al}^{3+}$ and $\mathrm{H}^{+}$ and considerable amounts of extractable $\mathrm{Ca}^{2}+\mathrm{Mg}^{2+}$ and $\mathrm{SO}_{4}{ }^{2-}$. These components show an important role in the soil acidity and affect seriously the crop production. Therefore, the present investigation was carried out to identify their water-soluble and exchangeable components and to elucidate the potential acidity of these soils. It is hoped that the obtained result helps the reclamation of such infertile soils.

\section{MATERIALS AND METHODS}

\section{Soil samples}

Acid sulfate soil samples used in this investigation were collected from 2 sites of a paddy field at the experimental farms of Cantho University in Vietnam and the same as those of the previous study (Huynh-tong-Tho and Egashira, 1976). Some of their mechanical and chemical properties are shown in Table 1. The sampling sites are located near the Bassac river, and flooded once a year in rainy season but not influenced by sea water intrusion (Fig. 1). The dotted line of $0.4 \mathrm{~g} \mathrm{NaCl} / 1$ shows the sea water intrusion.

\section{Extraction and determination of water-soluble and extractable components}

Duplicate $5 \mathrm{~g}$ air-dried soil samples $(<2 \mathrm{~mm})$ were placed in polyethylene bottles $(60 \mathrm{ml}$ in volume) with $50 \mathrm{ml}$ of distilled water or $1 \mathrm{M} \mathrm{KCl}$. Solution of $1 \mathrm{M} \mathrm{NaNO}_{3}$ was used to extract $\mathrm{Cl}^{-}$and $1 \mathrm{M} \mathrm{NH}_{4} \mathrm{Cl}$ for $\mathrm{K}+$. The soil suspensions were shaken for 3 hours followed by centrifugation and filtration.

The soil extracts were then analyzed for the following components :

1. Total acid by titration with $0.1 \mathrm{M} \mathrm{NaOH}$

2. $\mathrm{Fe}^{3+}$ and $\mathrm{Al}^{3+}$ by atomic absorption spectrophotometer

3. $\mathrm{Ca}^{2+}$ and $\mathrm{Mg}^{2+}$ by titration with $0.01 \mathrm{M}$ EDTA

4. $\mathrm{Na}^{+}$and $\mathrm{K}^{+}$by flame photometer

5. $\mathrm{NH}_{4}{ }^{+}, \mathrm{Cl}^{-}$and $\mathrm{NO}_{3}{ }^{-}$by ionmeter

6. SO,"- based on the Versene chelation of the excess Ba remaining after 
Table 1. Some mechanical and chemical properties of Vietnam acid sulfate soils.

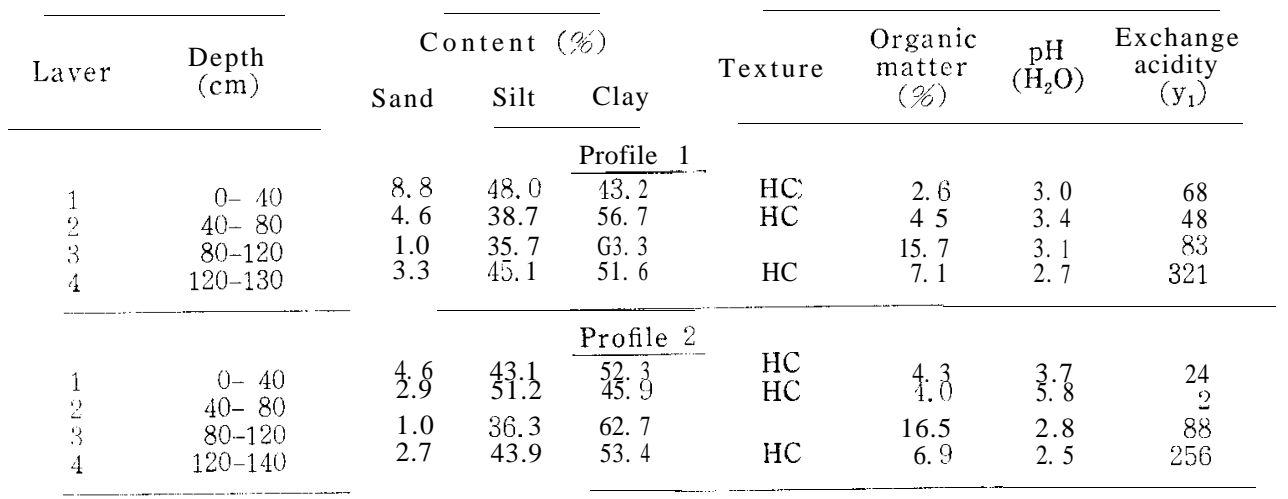

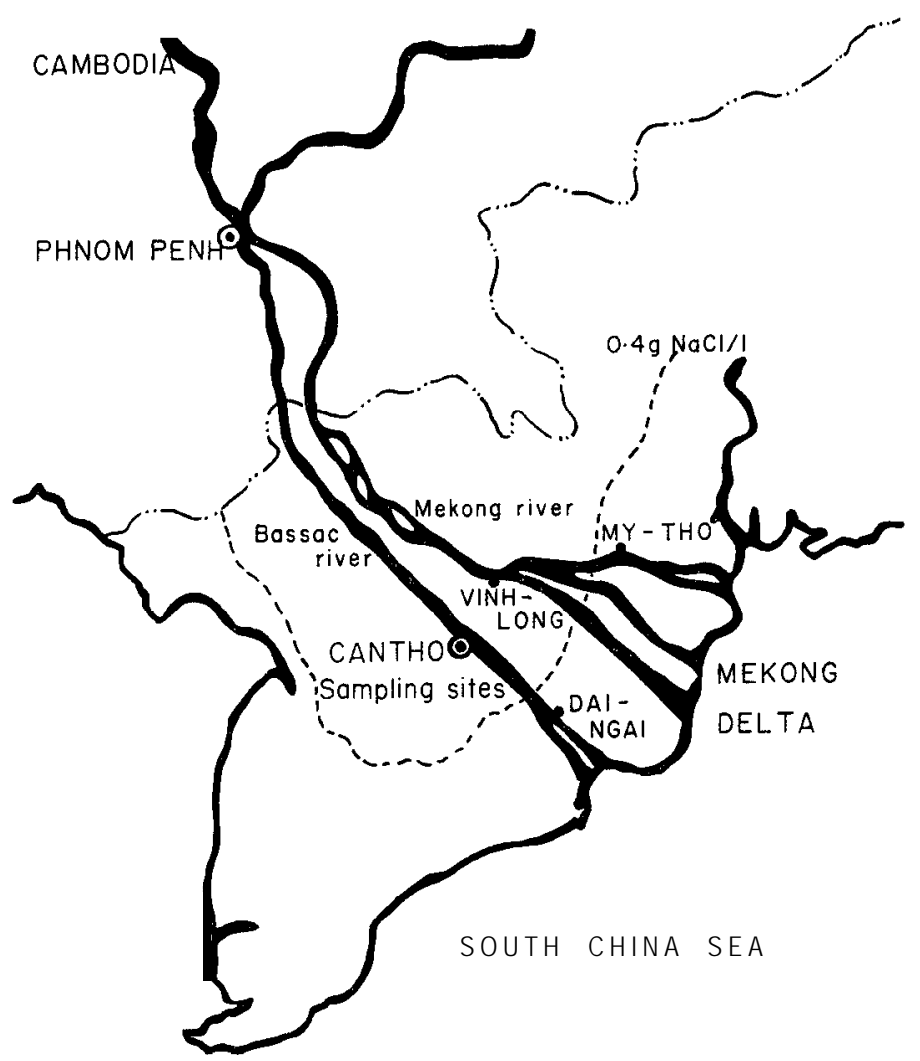

Fig. 1. Location of sampling sites of Vietnam acid sulfate soils. 
$\mathrm{BaSO}_{4}$ precipitation by addition of $\mathrm{BaCl}_{2}$ (Jackson, 1958).

Single and 5 -time extractions of $\mathrm{KCl}$-extractable components gave similar results (Table 2). Therefore, the data of single extraction were reported in this paper.

Table 2. Comparison of single and five-time extractions of $\mathrm{KCl}-\mathrm{ex}-$ tractable components (Profile 2).

\begin{tabular}{|c|c|c|c|c|c|c|}
\hline \multirow{3}{*}{ Layer } & \multirow{3}{*}{$\begin{array}{l}\text { Number of } \\
\text { extraction }\end{array}$} & \multirow{3}{*}{\multicolumn{3}{|c|}{$\begin{array}{r}\mathrm{Fe}^{3+} \quad \mathrm{Al}^{3+} \\
\mathrm{me} / 100 \mathrm{~g}\end{array}$}} & \multirow{3}{*}{$\mathrm{Ca}^{2+}+\mathrm{Mg}^{2+}$} & \multirow{3}{*}{$\mathrm{SO}_{4}{ }^{2-}$} \\
\hline & & & & & & \\
\hline & & & & & & \\
\hline 1 & $\begin{array}{l}1 \\
5\end{array}$ & $\begin{array}{l}8.0 \\
\text { a. }\end{array}$ & $\begin{array}{l}0.4 \\
0.7\end{array}$ & $\begin{array}{l}5.4 \\
5.2\end{array}$ & $\begin{array}{l}\text { 29. } 3 \\
\text { 29. } 4\end{array}$ & $\begin{array}{l}19.2 \\
18.3\end{array}$ \\
\hline 2 & $\begin{array}{l}1 \\
5\end{array}$ & $\begin{array}{l}0.0 \\
0.0\end{array}$ & $\begin{array}{l}0.0 \\
0.0\end{array}$ & $\begin{array}{l}0.0 \\
0.0\end{array}$ & $\begin{array}{l}35.1 \\
36.9\end{array}$ & $\begin{array}{l}\text { 16. } 7 \\
\text { 16. } 5\end{array}$ \\
\hline .3 & $\begin{array}{l}1 \\
5\end{array}$ & $\begin{array}{l}31.4 \\
33.7\end{array}$ & $\begin{array}{l}0.7 \\
1.4\end{array}$ & $\begin{array}{l}24.3 \\
27.5\end{array}$ & $\begin{array}{l}49.9 \\
50.9\end{array}$ & $\begin{array}{l}60.6 \\
60.5\end{array}$ \\
\hline 4 & $\begin{array}{l}1 \\
5\end{array}$ & $\begin{array}{l}61.2 \\
62.9\end{array}$ & $\begin{array}{l}\text { 28. } 1 \\
\text { 30. } 0\end{array}$ & $\begin{array}{l}30.0 \\
29.7\end{array}$ & $\begin{array}{l}36.0 \\
35.9\end{array}$ & $\begin{array}{l}74.0 \\
74.0\end{array}$ \\
\hline
\end{tabular}

Duplicate $2 \mathrm{~g}$ air-dried soil samples were treated for 3 times with $10 \mathrm{ml}$ of $35 \% \mathrm{H}_{2} \mathrm{O}_{2}$. Water-soluble and $\mathrm{KCl}$-extractable components were extracted for 3 times with distilled water or $1 \mathrm{M} \mathrm{KCl}$ and determined as described above.

\section{RESULTS AND DISCUSSION}

The amounts of water-soluble and exchangeable components of air-dried soil samples are shown in Table 3. The amounts of exchangeable components were calculated by subtracting the amounts of water-soluble ones from those of $\mathrm{KCl}$-extractable ones. The main cations were $\mathrm{Fe}^{3+}, \mathrm{Al}^{3+}, \mathrm{H}^{+}, \mathrm{Ca}^{2+}$ and $\mathrm{Mg}^{2+}$ and the main anion was $\mathrm{SO}_{4}{ }^{2-}$. Other cations $\left(\mathrm{Na}+, \mathrm{K}+\right.$ and $\left.\mathrm{NH}_{4}{ }^{+}\right)$and anions $\left(\mathrm{Cl}^{-}\right.$and $\left.\mathrm{NO},-\right)$ were present in amounts of less than $1 \mathrm{me} / 100 \mathrm{~g}$, respectively. So, they are not presented here. There were large amounts of water-soluble ions. Their amount and the ratio of the amounts of water-soluble ions to those of the exchangeable ions increased with the decreasing $\mathrm{pH}$. The total amount of water-soluble $\mathrm{Fe}^{3+}, \mathrm{Al}^{3+}, \mathrm{H}+, \mathrm{Ca}^{2+}$ and $\mathrm{Mg}^{2+}$ showed similar values with the amount of water-soluble $\mathrm{SO}_{4}{ }^{2-}$. Therefore, these cations are considered to be present in the soil under the form of sulfates.

$\mathrm{Fe}^{3+}, \mathrm{Al}^{3+}$ and $\mathrm{H}+$ are responsible for the soil acidity. The amount of $\mathrm{H}+$ was calculated by subtracting the amount of $\mathrm{Fe}^{3+}+\mathrm{Al}^{3+}$ from the total amount of titratable acid. The soil acidity was derived from water-soluble and exchangeable components. Water-soluble acid components are iron and aluminum sulfates and free sulfuric acid. The strong acidity at low $\mathrm{pH}(<2.7)$ was due to water-soluble iron and aluminum sulfates. At $\mathrm{pH}>2.8$ water-soluble $\mathrm{Fe}^{3+}$ disappeared and the contribution to the acidity of exchangeable $\mathrm{Al}^{3+}$ and aluminum sulfate increased. Water-soluble $\mathrm{Al}^{3+}$ at $\mathrm{pH}$ less than 3 varied from 6 
Table 3. Water-soluble and exchangeable components of air-dried Vietnam acid sulfate soils.

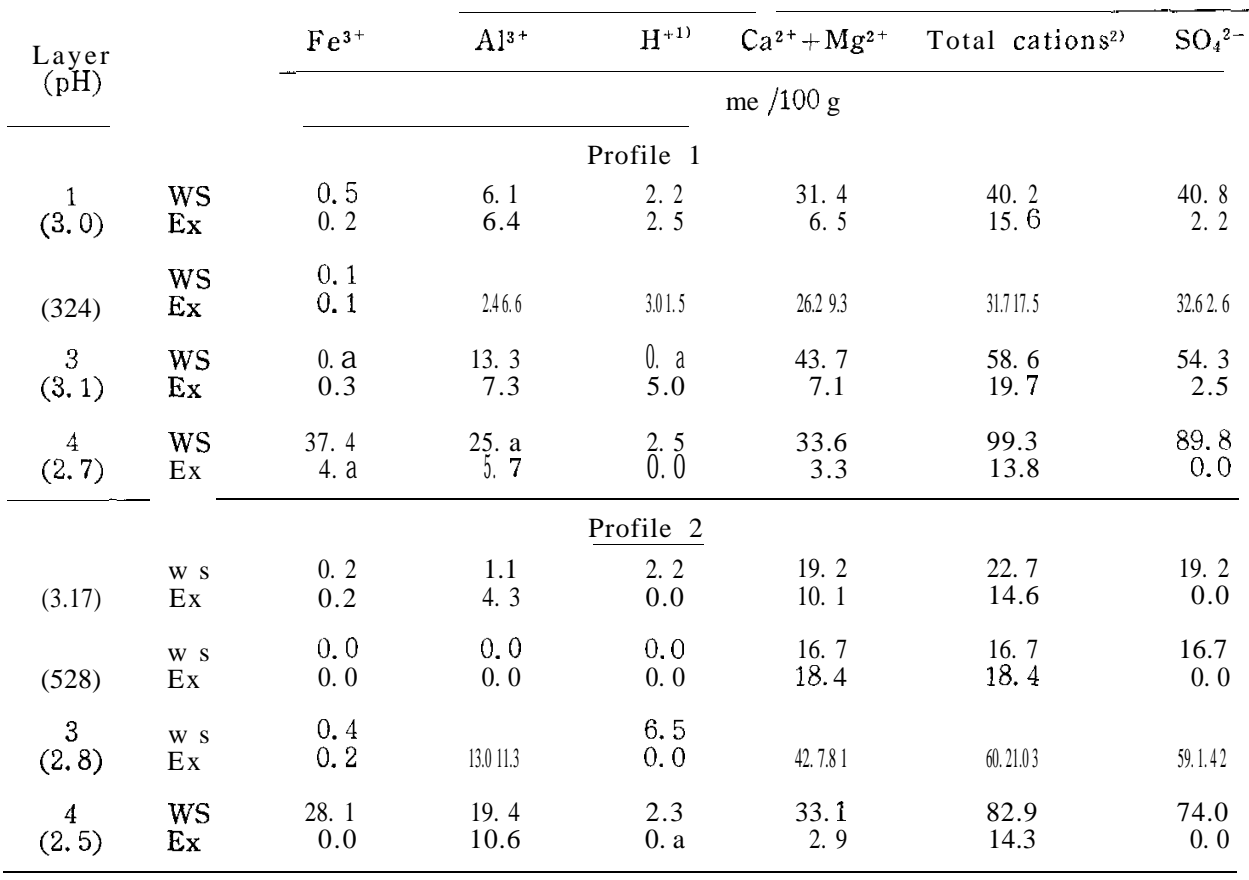

WS : Water-soluble.

Ex : Exchangeable (KCl-extractable-water-soluble).

1) Calculated by [Total acid- $\left.\left(\mathrm{Fe}^{3+}+\mathrm{Al}^{3+}\right)\right]$.

2) Total of $\mathrm{Fe}^{3+}, \mathrm{Al}^{3+}, \mathrm{H}^{+}, \mathrm{Ca}^{2+}$ and $\mathrm{Mg}^{2+}$.

to $25 \mathrm{me} / 100 \mathrm{~g}$ and kept the same as or higher than that of acid sulfate soils from Malaysia ( $8.5 \mathrm{me} / 100 \mathrm{~g}$ ) (Allbrook, quoted from Bloomfield and Coulter (1973)) and from Naka-umi, Japan ( $<7 \mathrm{me} / 100 \mathrm{~g}$ ) (Murakami, 1968a).

Water-soluble $\mathrm{Ca}^{2+}+\mathrm{Mg}^{2+}$ were present in considerable amounts. Their values were $17-44 \mathrm{me} / 100 \mathrm{~g}$ throughout the profiles and higher than those of other acid sulfate soils ( $<10 \mathrm{me} / 100 \mathrm{~g}$ ) from the Guinea coast (Horn and Chapman, 1968), from Naka-umi, Japan (Murakami, 1968b) and from Thailand (Breemen and Harmsen, 1975). Acid sulfate soils located in the coastal areas under conditions of periodic salt water intrusion often contain considerable amounts of water-soluble ions, mainly $\mathrm{Na}+$ and $\mathrm{Cl}$ - (Horn and Chapman, 1968; Breemen and Harmsen, 1975). The soil samples used in this investigation, containing very small amounts of water-soluble $\mathrm{Na}+$ and $\mathrm{Cl}^{-}$, were not influenced by sea water intrusion and had no application of lime. Therefore, so large amounts of water-soluble $\mathrm{Ca}^{2+}+\mathrm{Mg}^{2+}$ seem to be due to the intrusion of the Bassac river water in rainy season. Water analyses of the Bassac and Mekong rivers are shown in Table 4. The amount of exchangeable $\mathrm{Ca}^{2+}+\mathrm{Mg}^{2+}$ was less than $10 \mathrm{me} / 100 \mathrm{~g}$ throughout the profiles and showed the same level as that of other acid sulfate soils (Sompatpanit, quoted from Bloomfield and Coulter, 
Table 4. Water analyses of the Bassac and Mekong rivers (Mekong Committee, Saigon).

\begin{tabular}{|c|c|c|c|c|c|c|c|c|c|c|c|}
\hline \multirow{2}{*}{ River } & \multirow{2}{*}{ Location } & \multicolumn{3}{|c|}{ Sampling date $\mathrm{pH}$} & \multirow[t]{2}{*}{$\mathrm{Ca}$} & $\mathrm{Mg}$ & \multirow[t]{2}{*}{$\mathrm{Al}$} & $\mathrm{Fe}$ & $\mathrm{Cl}$ & SO, & $\mathrm{HCO}_{3}$ \\
\hline & & & & & & & & \multicolumn{4}{|c|}{$\mathrm{ppm}$} \\
\hline \multirow[t]{4}{*}{ Bassac } & Cantho ${ }^{1)}$ & April & 1963 & 7.9 & 17. 2 & 4. 1 & & & \multirow[t]{2}{*}{6.1} & 16. 5 & \multirow[b]{2}{*}{64} \\
\hline & Dai-Ngai & Sept & 1971 & 7. 2 & 16. 8 & 1.9 & 6.2 & 1.7 & & 3.7 & \\
\hline & Vinh-Long & May & 1963 & a. 0 & 24.8 & 6.6 & & & 15.1 & 14.4 & \\
\hline & & & 1963 & 8.0 & 17. 2 & 2. 9 & & & $\mathrm{tr}$ & 7. 4 & \\
\hline \multirow[t]{3}{*}{ Mekong } & \multirow{3}{*}{ My-Tho } & May & 1971 & n. a & 31.3 & 5.8 & 19.2 & 0.9 & 36.6 & 11.0 & \\
\hline & & July & 1963 & 7.6 & 19. 2 & 4.9 & & & 7. 6 & 24.7 & \\
\hline & & Sept & 1971 & 1.9 & 16.4 & 1. 4 & 5.3 & 4.2 & 45.8 & 6.2 & 61 \\
\hline
\end{tabular}

n.a: Not available. tr : Trace. ${ }^{1)}$ Sampling sites.

1973; Mai-thi-my-Nhung and Ponnamperuma, 1966; Pham-huu-Anh et al., 1961), except the second layer of profile 2 with pH 5.8 where the amount of exchangeable $\mathrm{Ca}^{2+}+\mathrm{Mg}^{2+}(18.4 \mathrm{me} / 100 \mathrm{~g})$ exceeded that of water-soluble $\mathrm{Ca}^{2+}+$ $\mathrm{Mg}^{2+}(16.7 \mathrm{me} / 100 \mathrm{~g})$.

The soil samples were oxidized by treating with $\mathrm{H}_{2} \mathrm{O}_{2}$ and analyzed for water-soluble and exchangeable components in order to know their potential acidity. The data are shown in Table 5. The amounts of water-soluble $\mathrm{Fe}^{3+}$, $\mathrm{Al}^{3+}, \mathrm{H}+$ and $\mathrm{SO},-$ were remarkably increased after treating with $\mathrm{H}_{2} \mathrm{O}_{2}$, especially at the third and fourth layers. But there was almost no change in the amounts of the exchangeable components. The potential acidity of acid sulfate soils is due to sulfides, mainly pyrite (Bloomfield, 1972; Calvert and Ford, 1973; Murakami, 1961). If pyrite is completely oxidized by $\mathrm{H}_{2} \mathrm{O}_{2}$, ferric sulfate and sulfuric acid will be produced as follows: $2 \mathrm{FeS}_{2}+\mathrm{H}_{2} \mathrm{O}+15 \mathrm{O} \rightarrow \mathrm{Fe}_{2}\left(\mathrm{SO}_{4}\right)_{3}+\mathrm{H}_{2} \mathrm{SO}_{4}$. In this experiment, $\mathrm{Fe}^{3+}+\mathrm{H}^{+}$increase was proportional to $\mathrm{SO}_{4}^{2-}$ increase but usually kept higher than SO, - increase. And the increase of $\mathrm{Fe}^{3+}$ was 4-6 times higher than that of $\mathrm{H}^{+}$at the third layers, but the increase of $\mathrm{H}^{+}$was far exceeded that of $\mathrm{Fe}^{3+}$ at the fourth layers. These results show the incompleteness of the oxidation of S to SO, (Murakami, 1961) and the presence of other sulfides.

Water-soluble $\mathrm{Al}^{3+}$ was also increased by the $\mathrm{H}_{2} \mathrm{O}_{2}$-treatment, especially at the third layers with high organic matter content. This agrees with the result of Lefebre-Drouet who found that the destruction of organic matter in acid soils with $\mathrm{H}_{2} \mathrm{O}_{2}$ liberates large quantities of $\mathrm{Al}$ (quoted from Bloomfield and Coulter, 1973). This supports the contention that Al forms stable complexes with organic matter.

There was almost no change of both water-soluble and exchangeable $\mathrm{Ca}^{2+}$ $+\mathrm{Mg}^{2+}$ after treating with $\mathrm{H}_{2} \mathrm{O}_{2}$, except the second layer of profile 2 where the increase of water-soluble $\mathrm{Ca}^{2+}+\mathrm{Mg}^{2+}(16.9 \mathrm{me} / 100 \mathrm{~g})$ was nearly equal to the decrease of exchangeable $\mathrm{Ca}^{2+}+\mathrm{Mg}^{2+}(-14.4 \mathrm{me} / 100 \mathrm{~g})$. This indicates that the exchangeable $\mathrm{Ca}^{2+}$ and $\mathrm{Mg}^{2+}$ adsorbed on the organic matter became watersoluble after treating with $\mathrm{H}_{2} \mathrm{O}_{2}$. 
Table 5. Water-soluble and exchangeable components of air-dried Vietnam acid sulfate soils after treating with $\mathrm{H}_{2} \mathrm{O}_{2}$.

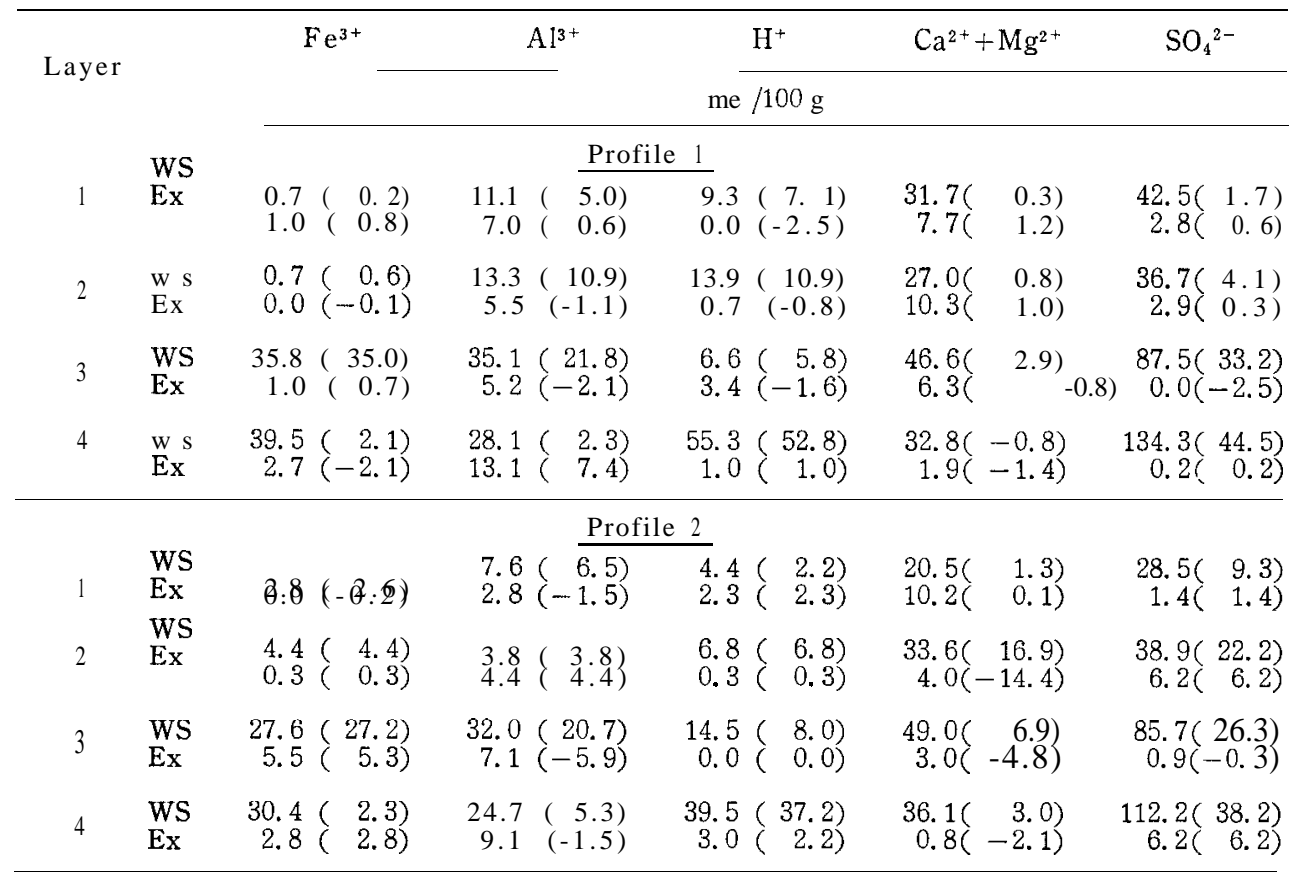

WS : Water-soluble. Ex : Exchangeable (KCl-extractable-water-soluble).

Values in the parentheses are increase or decrease by the $\mathrm{H}_{2} \mathrm{O}_{2}$-treatment.

\section{CONCLUSION}

Vietnam acid sulfate soils contained large amounts of water-solubleions of $\mathrm{Fe}^{3+}, \mathrm{Al}^{3+}, \mathrm{H}^{+}, \mathrm{Ca}^{2+}, \mathrm{Mg}^{2+}$ and $\mathrm{SO}_{4}^{2-}$. The strong acidity at low $\mathrm{pH}(<2.7)$ was due to water-soluble $\mathrm{Fe}$ and $\mathrm{Al}$ sulfates. At $\mathrm{pH}>2.8$ water-soluble $\mathrm{Fe}^{3+}$ disappeared and the contribution to the acidity of exchangeable $\mathrm{Al}^{3+}$ and $\mathrm{Al}$ sulfate increased. Considerable amounts of water-soluble $\mathrm{Ca}^{2+}$ and $\mathrm{Mg}^{2+}$ were ascribed to the intrusion of river water.

These soils showed the high potential acidity derived from sulfides especially in subsoil layers. The treatment with $\mathrm{H}_{2} \mathrm{O}_{2}$ caused the liberation of Al from organic matter.

\section{REFERENCES}

Bloomfield, C. 1972 The oxidation of iron sulfides in soils in relation to the formation of acid sulfate soils, and of ochre deposits in field drains. J. Soil Sci., 23: 1-16

Bloomfield. C. and J. K. Coulter 1973 Genesis and management of acid sulfate soils. Advan. Agron., 25: 265-326

Breemen N. van and K. Harmsen 1975 Translocation of iron in acid sulfate soils : I. 
Soil morphology, and the chemistry and mineralogy of iron in a chronosequence of acid sulfate soils. Soil Sci. Soc. Amer. Proc., 39: 1140-1148

Calvert, D. V. and H. W. Ford 1973 Chemical properties of acid sulfate soils recently reclaimed from Florida marshland. Soil Sci. Soc. Amer. Proc., 31 : 367-371

Horn, M. E. and S. L. Chapman 1968 Clay mineralogy of some acid sulfate soils on the Guinea coast. Trans. 9th Intern.Congr. Soil Sci., 3: 31-40

Horn, M. E., V. L. Hall., S. L. Chapman and M. M. Wiggins 1967 Chemical properties of the coastal alluvial soils of the Republic of Guinea. Soil Sci. Soc. Amer. Proc., 31: 108114

Huynh-tong-Tho and K. Egashira 1976 Some chemical, physical and mineralogical properties of acid sulfate soils from the Mekong delta in Vietnam. J.Fac. Agr., Kyushu Univ.. 20: 151-164

Jackson, M. L. 1958 Soil Chemical Analysis. Prentice-Hall, Inc., Englewood Cliffs, N. J.. pp. 263-266

Mai-thi-my-Nhung and F. N. Ponnamperuma 1966 Effects of calcium carbonate, manganese dioxide, ferric hydroxide and prolonged flooding on chemical and electrochemical changes and growth of rice in a flooded acid sulfate soil. Soil Sci., 102: 29-41

Moormann, F. R. 1963 Acid sulfate soils (cat-clays) of the tropics. Soil Sci.. 95: 271-275

Murakami, H. 1961 A method of semi-quantitative determination of oxidizable sulfur in polder soils by hydrogen peroxide (in Japanese). J. Sci. Soil and Manure, Japan, 32: 276-279

Murakami. H. 1968a Behaviour of mineral components of acid sulfate soil during the oxidation of oxidizable sulfur. Characteristics and improvement of acid sulfate soils (Part 4) (in Japanese). J. Sci. Soil and Manure. Japan, 39: 194-198

Murakami, H. 1968b Effect of sulfur oxidation on soil chemical nature and rice plant growth. Characteristics and improvement of acid sulfate soils (Part 5) (in Japanese). J. Sci. Soil and Manure, Japan, 39: 514-519

Pham-huu-Anh, F. R. Moormann and J. D. Golden 1961 Liming experiments on acid sulfate soils. In "Researches on Acid Sulfate Soils and Their Amelioration by Liming," ed. by Ministry of Rural Affairs in Vietnam, pp. 19-52 